\title{
Analysis of municipal waste generation rate in Poland compared to selected European countries
}

\author{
Beata Klojzy-Karczmarczyk ${ }^{1 *}$, and Said Makoudi ${ }^{2}$ \\ ${ }^{1}$ Mineral and Energy Economy Research Institute, Polish Academy of Sciences, Wybickiego 7A, 31-261 Krakow, Poland \\ ${ }^{2}$ Mineral and Energy Economy Research Institute, Polish Academy of Sciences, Wybickiego 7A, 31-261 Krakow, Poland
}

\begin{abstract}
The generated municipal waste rates provided in the planning documents are a tool for forecasting the mass of waste generated in individual waste management regions. An important issue is the decisive separation of two concepts: waste generated and waste collected. The study includes analysis of the generation rate for Poland with division into urban and rural areas. The estimated and projected rate of municipal waste generation for Poland provided in subsequent editions of National Waste Management Plans (KPGO) changed since 2000 within wide range from about 300 to more than $500 \mathrm{~kg}$ per capita in an individual year (kg/pc/year). Currently, the National Waste Management Plan for the years 2017-2022 estimates municipal waste generation rate at approx. $270 \mathrm{~kg} /$ per capita/year with a projected increase to 330 $\mathrm{kg} /$ per capita/year in 2030. Most European countries adopt higher municipal waste generation rate, often exceeding $600 \mathrm{~kg} /$ per capita/year. The objective of the paper is therefore to analyze the causes of this difference in the declared values. The morphological composition of municipal waste stream in Poland and in selected European countries (e.g. France, Belgium, Switzerland) was analyzed. At present it is not possible to balance the value of the generation rate with the rate of waste collection in Poland. The conducted analyzes allow for determining a number of reasons for variation of the rate value in particular countries, mostly morphological composition of municipal waste, inclusion of household-like waste from infrastructure facilities or not and amount of waste collected in rural areas. The differences in the generation rates and provided possible reasons indicate the need to harmonize the methodology for estimating rates of municipal waste generation in various countries, including Poland.
\end{abstract}

\section{Introduction}

The planning of municipal waste management is closely linked to the need to develop reliable rates of waste generation with the share of individual morphological fractions throughout the stream. The mass and quality of municipal waste generated by the inhabitants vary for urban and rural areas. The ecological awareness of the community is also differentiated, which significantly influences the condition of waste management, mainly the volume of generation, collection, management of waste and issues related to the possibility of creating illegal waste disposal sites [ie. 1-4].

The composition of municipal waste is dominated by raw materials (paper and cardboard 5-19\%, glass ca. $10 \%$, plastics $10-15 \%$ and metals) and biodegradable waste (29-33\%), collected selectively or separated in mechanical-biological processing installations for various purposes [5-11]. Due to the nature of heating individual households and using hard coal for this purpose $[12,13]$, the waste from coal combustion is also important in the stream of municipal waste, and their quantity is strictly related to the quality of the burned raw material [14]. These waste contributes to the fine fraction $<10 \mathrm{~mm}$ and to the mineral waste. Particularly high share of these waste in the morphological composition is observed for rural areas, where fine fraction reaches $17 \%$ and mineral waste reach $6 \%[15$, $20,21]$.

The study includes an analysis of the rate of municipal waste generation since the beginning of planning activities in the waste management sector in Poland, ie. since 2000. Literature analysis has shown that rates for municipal waste generation vary for European countries. The morphological composition of municipal waste stream in Poland and selected European countries (e.g. France, Belgium, Switzerland) was therefore analyzed. For Poland, a stream of generated municipal waste collected both selectively and as mixed waste was analyzed in division into three groups: a large city (over 50,000 inhabitants), a small town (less than 50,000 inhabitants) and rural areas. The generated municipal waste rates provided in the planning documents are a tool for forecasting the mass of waste generated in individual waste management regions and thus for the design of the demand for municipal waste processing facilities and their processing capacity.

The objective of the presented work is to show the existing differences in the values of generation indicators for Poland and selected European countries and to search

* Corresponding author: beatakk@min-pan.krakow.pl 
for the reasons for such a situation. The essence of the work is to show differences in the morphological composition of the municipal waste stream despite the same definitions adopted in each country.

\section{Generation rate in Poland in the years 2000-2016}

The conducted morphological investigations of municipal waste and their collection rates in individual years are the basis for the estimation of municipal waste generation rates. Over the years, these rates have been developed using a variety of methods, taking into account the waste collection volume, the guidelines of relevant standards and mainly concerned the large urban agglomerations [16, 17]. This way, the estimated national rates together with the morphology of waste are further used to develop the voivodship waste management plans.

In the subsequent editions of National Waste Management Plans (KPGO), the municipal waste generation rate has changed since 2000 between 353 and $280 \mathrm{~kg} /$ per capita/year (kg/pc/year) (Table 1). In addition, the national plans adopted by the resolutions from 2003 [18] and 2010 [20] separately provide rates for urban areas (424-346 kg/pc/year) and rural areas (223-234 kg/pc/year). Generation rates in particular years have been compiled on the basis of the volume of waste collection in the so-called base year (Table 1), preceding the development of a specific plan. Moreover, based on the current situation, at the beginning of the planning activities the projected generation rate values over the years even exceeded $500 \mathrm{~kg} /$ per capita/year (Table 1). In subsequent editions of national plans, however, the projected rates were lower. As a result, the projected generation of municipal waste was equated to the collected waste (Fig. 1, Table 1,2) both in the base year in 2014 and in the years for which the forecast was prepared.

Table 1. Generation of municipal waste in Poland.

\begin{tabular}{|c|c|c|c|c|}
\hline $\begin{array}{c}\text { Data } \\
\text { source }\end{array}$ & $\begin{array}{c}\text { Base } \\
\text { year }\end{array}$ & $\begin{array}{c}\text { Genera- } \\
\text { tion } \\
{[\mathrm{Gg}]}\end{array}$ & $\begin{array}{c}\text { Estimated } \\
\text { generation } \\
\text { rate } \\
{[\mathrm{kg} / \mathrm{pc} / \text { year }]}\end{array}$ & $\begin{array}{c}\text { Projected } \\
\text { generation } \\
\text { rates in years } \\
{[\mathrm{kg} / \mathrm{pc} / \text { year }]}\end{array}$ \\
\hline $\begin{array}{c}\text { KPGO } \\
2006 \\
{[18]}\end{array}$ & 2000 & 13,503 & 353 & $\begin{array}{c}2005: 407 \\
2010: 458 \\
2014: 522\end{array}$ \\
\hline $\begin{array}{c}\text { KPGO } \\
2010\end{array}$ & 2004 & 11,802 & 309 & $\begin{array}{c}2010: 289 \\
{[19]}\end{array}$ \\
\hline $\begin{array}{c}\text { KPGO } \\
2014 \\
{[20]}\end{array}$ & 2008 & 12,101 & 314 & $2018: 301$ \\
\hline $\begin{array}{c}\text { KPGO } \\
2022 \\
{[21]}\end{array}$ & 2014 & 10,804 & 280 & $2014: 339$ \\
\hline \multicolumn{2}{|c|}{ KPG } & & & $2020: 377$ \\
\hline
\end{tabular}

KPGO - the National Waste Management Plan

The lowest generation rates are provided in the latest national plan for the years 2017-2022 [21]. Currently, the National Waste Management Plan for the years
2017-2022 estimates municipal waste generation rate at approx. 270-280 kg/per capita/year (depending on the source of the data) with a projected increase to 330 $\mathrm{kg} /$ per capita/year in 2030 . The information provided by the Central Statistical Office [22] in some cases differs slightly from the numbers reported in national planning documents, however, the tendency of change is maintained (Fig. 1). The National Waste Management Plan 2022 [21] assumes a unified municipal waste generation rate, regardless of the nature of the area, although the shares of the individual morphological fractions differ. It also assumes a practical equalization of the volume generated and collected and the increase of the rate in individual years according to two variants: low hypothesis (annual increase in the amount of generated municipal waste per inhabitant will be at $0.6 \%$ ) and high hypothesis (annual increase will be at $1 \%$ ). Table 1 provides forecasts of generation according to the high hypothesis.

Table 2. Collection of municipal waste in Poland

\begin{tabular}{|c|c|c|c|}
\hline Data source & $\begin{array}{c}\text { Base } \\
\text { year }\end{array}$ & $\begin{array}{c}\text { Collection } \\
{[\mathrm{Gg}]}\end{array}$ & $\begin{array}{c}\text { Calculated } \\
\text { collection } \\
\text { rate } \\
{[\mathrm{kg} / \mathrm{pc} / \text { year }]}\end{array}$ \\
\hline KPGO 2006 [18] & 2000 & 12,226 & 319 \\
\hline KPGO 2010 [19] & 2004 & 9,800 & 256 \\
\hline KPGO 2014 [20] & 2008 & 10,036 & 263 \\
\hline KPGO 2022 [21] & 2014 & 10,804 & 280 \\
\hline
\end{tabular}

KPGO - the National Waste Management Plan

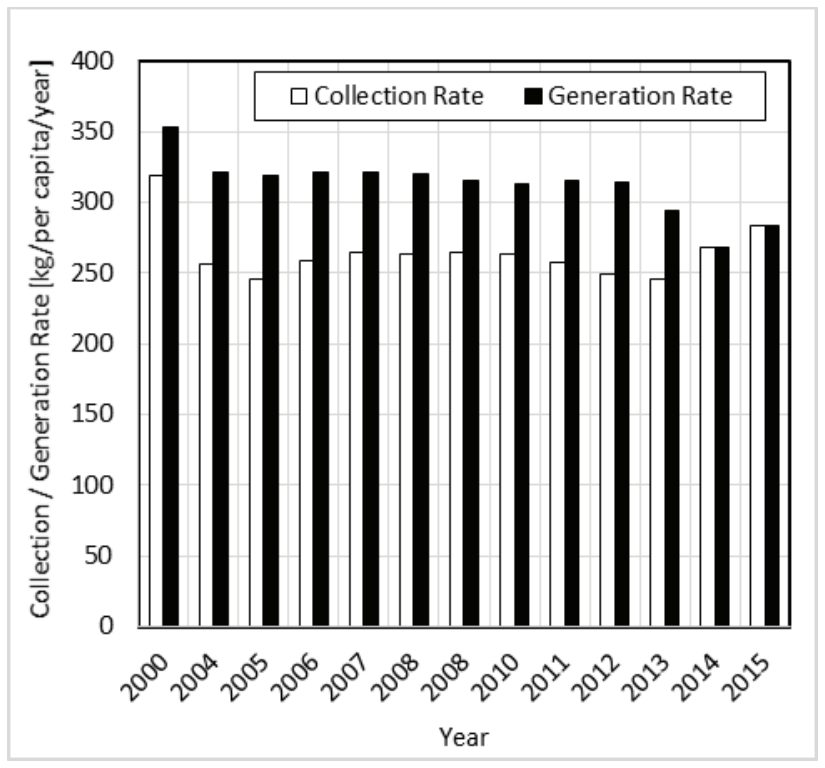

Fig. 1. Comparison of generation and collection rates for Poland in the years 2000-2015 [21,22].

\section{Generation rate in the European countries}


The average rate of municipal waste generation in Europe, calculated on the basis of 27 countries excluding Poland, was $475 \mathrm{~kg}$ per capita in 2013 [23]. In the same year, the generation rate for Poland was 294 [21], which was significantly lower than the EU average. Such a trend has been maintained for many years (Fig. 2). The analysis prepared and published in 2012 by E. Kaca \& G. Kaca [24] highlights these discrepancies in municipal waste generation in Poland and other EU countries.



Fig. 2. Comparison of rates of municipal waste generation in EU countries and Poland in the years 2005-2014 [21,23].

Poland is among the countries with the lowest rate of municipal waste generation, together with Romania and Estonia (Table 3). According to Eurostat data [23], the generation of municipal waste in EU countries was in the range of 254 to $752 \mathrm{~kg} / \mathrm{per}$ capita/year in 2013. The highest generation of municipal waste for many years has been recorded in Denmark and the lowest for Romania (Table 3).

Table 3. Rates of municipal waste generation in European countries $[23,29]$.

\begin{tabular}{|c|c|}
\hline $\begin{array}{c}\text { Waste generation } \\
\text { in 2013 } \\
{[\mathrm{kg} / \text { per capita/year }]}\end{array}$ & European countries \\
\hline$<300$ & Poland, Estonia, Romania \\
\hline $300-400$ & $\begin{array}{c}\text { Czech Republic, Latvia, } \\
\text { Slovakia, Hungary }\end{array}$ \\
\hline $400-500$ & $\begin{array}{c}\text { Belgium, Bulgaria, Croatia, } \\
\text { Finland, Spain, Lithuania, Portugal, } \\
\text { Slovenia, Sweden, United } \\
\text { Kingdom, Italy }\end{array}$ \\
\hline $500-600$ & $\begin{array}{c}\text { Austria, France, Greece, } \\
\text { Netherlands, Ireland, Malta }\end{array}$ \\
\hline $600-700$ & $\begin{array}{c}\text { Cyprus, Luxembourg, Germany } \\
\text { Denmark, Switzerland [29] }\end{array}$ \\
\hline$>700$ & Denter \\
\hline
\end{tabular}

Rates of municipal waste generation in different European countries are undoubtedly dependent on the actual volume of generation and collection, and thus consumption and wealth of the population. They may also be the result of a varied level of ecological awareness of the inhabitants, and consequently the process of minimizing waste generation, according to the hierarchy of waste management. In search for reasons for differentiation of generation rates in individual countries, however, attention should be paid to the interpretations of the meaning of expressions concerning waste generated and collected and to the range of morphological fractions that feed the municipal waste stream.

\section{Municipal waste stream in selected European countries}

\subsection{Methodology of analysis}

French-speaking countries (Switzerland, France and Belgium) were selected for the analysis of the generation rate and the municipal waste stream. Alongside Denmark, one of the highest generation rates may be found in Switzerland (729 kg/pc/year in 2014 [29], Denmark - $758 \mathrm{~kg} / \mathrm{pc} /$ year in 2014 [23]). On the other hand, France and Belgium show modest generation rate values, close to the EU average [23] (Table 3). The values of the generation indicators were reported in statistical and planning documents for each country. The methodology for estimating these indicators was not analyzed, but the morphological stream feeding the municipal waste was. Such procedure allowed to identify the possible causes of such different values.

The following section (section 4.3) contains a simulation showing how the generation rate for Poland will change if municipal waste collected in infrastructure facilities is included in the estimation process and the collection of waste in rural areas is increased. It was assumed that the generation rate currently announced for Poland is based only on waste collected in individual households. The volume of generated waste calculated on this basis was increased by the mass that could be collected from the infrastructure facilities and by the mass allegedly generated (but presumably not collected and utilized by the households) in rural areas.

\subsection{Analysis of morphological composition of waste}

The European Environment Agency, in spite of the different definitions of municipal waste used in each country, uses the definition of municipal waste management $[23,25]$, which states that municipal waste is waste primarily generated by households and similar waste from such sources like trade, offices and public institutions (household-like waste). The amount of municipal waste generated consists of waste collected by the municipal authorities or on their behalf and disposed of in accordance with the adopted waste management system. It should be noted that according to this definition, the terms waste generated and waste collected are identical and expressed in the same way. 
Poland. According to the Waste Act [26], municipal waste is household waste and non-hazardous waste from other waste producers which, by its nature or composition, is similar to household waste. According to the National Waste Management Plan 2010 [19], municipal waste in Poland in $2 / 3$ consists of household waste and in $1 / 3$ of waste from infrastructure. Municipalities receive waste from all residential properties, while non-residential waste (including infrastructure) is not routinely received by the municipality, so it may not be included in the reporting. In addition, the morphological studies from Poland poorly take into account rural areas in the stream of municipal waste. This areas, which are inhabited by $40 \%$ of the country's population, are not representative regarding both the quantity and morphological composition of municipal waste. The majority of waste generated in rural areas is managed on one's own account. Generally, the following waste is collected, selectively or in a mixed manner: glass, metals, plastics, multi-material waste, textiles, hazardous waste, largesize waste, accounting for approximately $30 \%$ of the total mass of waste generated in rural areas. It is estimated that the remaining waste is managed on one's own account to the extent of about $70 \%$. Selfmanagement of waste definitely lowers generation rates, which are based on the size of waste collection.

France. Municipal waste is all waste (household and waste from infrastructure - similar to municipal waste, collected in the same manner as household waste) and management of these waste is within the competence of a local government unit [27]. Municipal waste includes mixed household waste, household waste selectively collected, business waste similar to municipal waste, large-size household waste, waste collected at selective waste collection points, household hazardous waste, street and square cleaning waste, green waste from households and infrastructure, and additionally sediments from sewage treatment plants. In France, according to Eurostat data [23], the municipal waste generation rate was $535 \mathrm{~kg}$ per capita in 2009, according to data from the French Environmental Protection Agency - Ademe [27] $374 \mathrm{~kg} /$ per capita/year in households alone, while $318 \mathrm{~kg}$ per capita was collected from these households in the analyzed year.

Switzerland. In Switzerland, waste is subdivided into four basic categories: construction waste, municipal ("urban") waste, hazardous waste and sewage sludge. Urban (municipal) waste is household waste and similar waste generated by handicrafts and the service sector, unless these entities employ more than 250 employees [28]. These is waste consisting of waste from households, administrative buildings, small farms, squares and gardens, public utility buildings and streets [29]. The analysis of data shows that urban waste is composed of household waste and mixed municipal waste from the infrastructure. Generation (115,000 $118,000 \mathrm{Mg}$ ) of urban waste expressed in $\mathrm{kg}$ per capita per year show similar values between 600 and $660 \mathrm{~kg}$ per capita in particular years between 1990 and 2005 . The rate of generation of household waste in 2005 alone was slightly less than $480 \mathrm{~kg}$ per capita $[29,30]$.
Belgium. Municipal waste is household and household-like waste. Municipal waste is waste collected by municipal services, in the selective collection stations, sweeping machines, excluding construction materials [31]. In Belgium, $436 \mathrm{~kg} /$ per capita/year of municipal waste was generated in 2014, composed of mixed waste and selectively collected waste $[23,31]$. In addition, the Wallonia Government Regulation of 5 March 2008 on household waste management and incurred costs defines gross household waste as residual household waste after subtraction of the fractions sorted by residents [32]. The amount of gross domestic waste generated in urban areas is $130 \mathrm{~kg} / \mathrm{per}$ capita/year, whereas urban-rural areas generate only $102 \mathrm{~kg} / \mathrm{per}$ capita/year. Gross household waste generation in $\mathrm{kg} / \mathrm{per}$ capita/year is $27 \%$ higher in urban areas [32].

In reference to the above interpretations of the definition of municipal waste in different countries, it should be noted that the term "municipal waste" is used in different ways in European countries, depending on the adopted waste management system. Differences between countries to some extent result from the inclusion or exclusion of certain types of waste in municipal waste streams (eg. sewage sludge, householdlike waste from infrastructure). The actual and provided rates of municipal waste generation and management are also affected by the amount of waste generated from the infrastructure and the share of rural areas in the countries where the volume of generation is significantly underestimated.

\subsection{Simulation of the generation rate for Poland}

On the basis of the analysis one can notice that the generation rates for Poland are among the lowest in Europe. It could be assumed that the generation rates estimated for Poland could rise and become equal to the average value of rates for the EU when infrastructure waste and actual amounts of waste from rural areas, underestimated by the current collection and forecasting system are included in the municipal waste stream. In order to estimate the value, a forecast has been prepared in this paper, taking into account the increase in generation in these two areas, which, in real terms, undoubtedly necessitates an increase in the efficiency of collection in these areas. The expected results of these activities are presented in Table 4.

The simulation was conducted for 2014, which is the base year in the current KPGO 2022. It is possible to assume that additional $20 \%$ of the mass of waste corresponding to the mass of waste generated in the infrastructure should be taken into account (the waste generated from the infrastructure is $30 \%$ of the total [19]) and $70 \%$ of the mass from rural areas (in the case of Poland this means $40 \%$ of the country's population). Under such assumptions, the generation rate could increase even up to $540 \mathrm{~kg} /$ per capita/year (option I). In the other variant (variant II of the simulation), lower mass values of waste included in the municipal waste stream were adopted, reflecting waste generation from the infrastructure and rural areas at $15 \%$ and $50 \%$, 
respectively. Such a procedure allowed to obtain the value of generation rate for Poland at $432 \mathrm{~kg} / \mathrm{per}$ capita/year. The average of these two variants provides a waste generation rate of $486 \mathrm{~kg} /$ per capita/year. This way, the value of generation rates is comparable to the average value obtained for other countries at $475 \mathrm{~kg} /$ per capita/year.

Table 4. Simulation of the rate of municipal waste generation for Poland, taking into account the assumed generation volumes from infrastructure facilities and from rural areas.

\begin{tabular}{|c|c|c|c|c|}
\hline Simulated values for & \multicolumn{2}{|c|}{ Variant I } & \multicolumn{2}{c|}{ Variant II } \\
\cline { 2 - 5 } $\begin{array}{c}\text { 2014 (base year for } \\
\text { KPGO 2022) }\end{array}$ & $\begin{array}{c}(1) \\
20 \%\end{array}$ & $\begin{array}{c}(2) \\
70 \%\end{array}$ & $\begin{array}{c}(1) \\
15 \%\end{array}$ & $\begin{array}{c}(2) \\
50 \%\end{array}$ \\
\hline $\begin{array}{c}\text { Assumed (additional) } \\
\text { generation: } \\
\text { infrastructure and } \\
\text { rural areas [Tg] }\end{array}$ & 4.16 & 5.82 & 2.49 & 3.32 \\
\hline $\begin{array}{c}\text { Total generation } \\
\text { (taking into account } \\
\text { infrastructure and } \\
\text { rural areas) [Tg] }\end{array}$ & \multicolumn{2}{|c|}{20.78} & & 16.62 \\
\hline $\begin{array}{c}\text { Population [million] } \\
\text { [22] }\end{array}$ & \multicolumn{3}{|c|}{38.46} \\
\hline $\begin{array}{c}\text { Simulated generation } \\
\text { rates (the expected } \\
\text { values) [kg/pc/year] }\end{array}$ & \multicolumn{2}{|c|}{540} & \multicolumn{2}{|c|}{432} \\
\hline
\end{tabular}

(1) infrastructure

(2) rural areas

\section{Summary and conclusions}

To a large extent the value of the generation rate adopted in the parent planning documents and then transferred to the downstream documents is the result of an interpretation of the amount of collected waste. In order to determine the demand for municipal waste processing plants, the amount of collected waste is significant, but the volume of waste generation is an important issue for the prediction of potential changes in the waste management system in each region of each country. The estimated and projected rate of municipal waste generation for Poland provided in subsequent editions of the National Waste Management Plans (KPGO) changed since 2000 within wide range: from about 300 to more than $500 \mathrm{~kg}$ per capita in an individual year $(\mathrm{kg} / \mathrm{pc} / \mathrm{year})$. Most European countries adopt higher municipal waste generation rate, often exceeding $600 \mathrm{~kg} / \mathrm{per}$ capita/year. The conducted analyzes allow for determining a number of reasons for variation of the rate value in particular countries:

- to a large extent the generation rates reflect the amount of waste collection, which in practice provides underestimated values;

- the share of morphological fractions in municipal waste streams is closely tied to the adopted municipal waste collection system in a given country;

- the morphological composition of the municipal waste is different in analyzed countries;

- the share in the municipal waste stream of waste from the infrastructure is variable and depends on the adopted and implemented system;
- the inclusion of household-like waste from infrastructure facilities in estimating the value of the generation rate is a necessary element;

- the amount of waste collected in rural areas is probably much lower than the volume actually produced;

- underestimation of generation in rural areas is a particularly important problem in countries with a high share of such areas, such as Poland;

- in estimating the rate of municipal waste generation in Poland, the mass of waste generated by the infrastructure and the predicted mass of waste to be collected in rural areas has a significant impact on increase of its value.

Reliable generation rates depend on the size and location of new investments related to the processing of municipal waste. The differences in the generation rates identified in the paper and provided possible reasons indicate the need to harmonize the methodology for estimating rates of municipal waste generation in various countries, including Poland.

An important issue in the management of municipal waste is the decisive separation of the meaning of concepts, including generated waste and collected waste. At present it is not possible to balance the value of the generation rate with the rate of waste collection in Poland, which is particularly important in rural areas. In order to obtain reliable indicators of municipal waste generation, it is necessary to conduct an up-to-date survey of the amount and composition of municipal waste in waste management regions, in line with the unified methodology developed jointly with other European countries.

It is difficult to identify the approach to the morphological composition of each country's municipal waste stream based on the Eurostat data provided, and caution should be exercised when comparing European countries, including those in the EU.

The publication was carried out in the framework of the statutory works of MEERI PAS.

\section{References}

1. W. Sobczyk, Aspekty społeczne $i$ środowiskowe gospodarki odpadami (Wyd. AGH Kraków, 2016) (in Polish)

2. W. Sobczyk, A. Biedrawa-Kozik, A. Kowalska, Rocznik Ochrona Środowiska (Annu. Set Environ. Prot.), 14, 262-273 (2012)

3. M. Mamak, A. Kicińska, Uniwersytet Zielonogórski Zeszyty Naukowe, 162, Inżynieria Środowiska 42, 138-154 (2016) (in Polish)

4. M. Żygadło, Gospodarka odpadami komunalnymi (Wyd. Politechniki Świętokrzyskiej, Kielce 2002) (in Polish)

5. B. Klojzy-Karczmarczyk, S. Makoudi, J. Staszczak, Rocznik Ochrona Środowiska (Annu. Set Environ. Prot.), 17, 1162-1177 (2015) (in Polish)

6. B. Klojzy-Karczmarczyk, J. Staszczak, Polityka Energetyczna - Energy Policy J. 20(2), 143-154 (2017) (in Polish) 
7. B. Klojzy-Karczmarczyk, S. Makoudi, J. Staszczak, Zeszyty Naukowe IGSMiE PAN, 87, 149-162 (2014) (in Polish)

8. S. Makoudi, J. Staszczak, Zeszyty Naukowe IGSMiE PAN, 84, 89-101 (2013) (in Polish)

9. Cz. Rosik-Dulewska, Podstawy Gospodarki Odpadami (Wyd. Naukowe PWN, 2011) (in Polish)

10. Cz. Rosik-Dulewska, Gospodarka Surowcami Mineralnymi - Mineral Resources Manage. 21, 5772 (2005) (in Polish)

11. P. Łach, K. Kiprian, Prace Instytutu Ceramiki i Materiałów Budowlanych, 7(18), 59-70 (2014) (in Polish)

12. K. Stala-Szlugaj, Gospodarka Surowcami Mineralnymi - Mineral Resources Manage. 32(3), 5-22 (2016)

13. K. Stala-Szlugaj, Rocznik Ochrona Środowiska (Annu. Set Environ. Prot. 13(2), 1877-1889 (2011) (in Polish)

14. K. Stala-Szlugaj, Rocznik Ochrona Środowiska (Annu. Set The Environ. Prot. 14, 909-918 (2012) (in Polish)

15. A. Jędrczak, Analiza dotyczaca ilości wytwarzanych oraz zagospodarowanych odpadów ulegajacych biodegradacji (Zielona Góra, 2010) (in Polish)

16. L. Sieja, Ochrona powietrza i problemy odpadów, 40(1), 28-33 (2006) (in Polish)

17. M. Malinowski, A. Woźniak, Infrastruktura i Ekologia Terenów Wiejskich, 13, 29-39 (2010) (in Polish)

18. M.P. [Official Gazette of the Republic of Poland] of 2003, No. 11, Item 159 (http://isap.sejm.gov.pl)

19. M.P. [Official Gazette of the Republic of Poland] of 2006, No. 90, Item 946 (http://isap.sejm.gov.pl)

20. M.P. [Official Gazette of the Republic of Poland] of 2010, No. 101, Item1183 (http://isap.sejm.gov.pl)

21. M.P. [Official Gazette of the Republic of Poland] of 2016. Item 784 (http://isap.sejm.gov.pl)

22. GUS, Central Statistical Office of Poland (http://stat.gov.pl/, on-line, accessed: 21.03.2017)

23. EUROSTAT, Eurostat Statistics Explained (http://ec.europa.eu/eurostat/, http://ec.europa.eu/eurostat/statistics-explained/, online, accessed: 25.04.2017)

24. E. Kaca, G. Kaca, Problemy Inżynierii Rolniczej, 3(77), 123-134 (2012)

25. European Environment Agency, Managing municipal solid waste, a review of achievements in 32 European countries, EEA Report 2/2013 (https://www.eea.europa.eu/, on-line, accessed: 21.03.2017)

26. Dz.U. [Journal of Laws] of 2013, Item 21 (http://isap.sejm.gov.pl)

27. ADEME, French Environment \& Energy Managenet Agency (http://www.ademe.fr/, on-line, accessed 24.04.2017) (in French)

28. République et canton de Genève, Plan de Gestion des Déchets du Canton de Genève 2014 -2017 (https://demain.ge.ch/document/plan-gestiondechets.../, on-line, accessed: 24.04.2017) (in French)
29. OFEV, Federal Office for the Environment (https://www.bafu.admin.ch/, on-line, accessed: 25.04.2017) (in French)

30. République et canton de Neuchatel, SCPE, Plan cantonal de gestion des déchets (http://www.ne.ch/, on-line, accessed: 24.04.2017) (in French)

31. Economie, Statistics Belgium (http://statbel.fgov.be/, on-line, accessed : 25.04.2017) (in French)

32. Service Public de Wallonie, Bilan du Plan wallon des déchets Horizon 2010, Volet déchets ménagers et assimilés (http://environnement.wallonie.be, on-line, accessed: 25.04.2017) (in French) 